\title{
As desigualdades fontes de dinâmicas urbanas no centro histórico de Lisboa
}

\author{
Inequalities as sources of urban dynamics \\ in the historic center of Lisbon
}

Jacques Galhardo

\section{Resumo}

0 centro histórico de Lisboa tornou-se, nos anos 1980, ponto fulcral para os agentes públicos locais que tentam torná-lo vitrine da capital e um dos motores das dinâmicas urbanas. Diferentemente do que foi escrito pelos anglo-saxões nos anos 1960, o enobrecimento socioespacial não aparece como objetivo. Pelo contrário, as políticas públicas procuram claramente manter e ajudar as populações instaladas nos bairros históricos da capital. Esse esforço está patente nas estatísticas ou nas próprias desigualdades persistentes, observadas nesse espaço. Longe de ser uma barreira, parece pelo contrário que essas políticas são um dos motores das dinâmicas em centro histórico.

Palavras-chaves: centro histórico; desigualdades; gentrification; Lisboa; agentes públicos.

\begin{abstract}
In the 1980s, the historic center of Lisbon became a major challenge for local public actors who have tried to make it the window of the capital city and one of the drivers of the urban dynamics. Unlike what was described by the Anglo-Saxons in the 1960s, socio-spatial gentrification never appears as a goal. Instead, public policies clearly seek to maintain and help the long-established population in the historic neighborhoods of the capital city. This effort is reflected in the statistics or in the persistent inequalities observed in the territory. Far from being a handicap, it seems that these policies are a driving force of the urban dynamics in the old city center.
\end{abstract}

Keywords: old center; inequality; gentrification; Lisbon; public actors. 


\section{Introdução}

Por hoje a questão das relações e as desigualdades e aquilo a que os pesquisadores anglo-saxões chamaram a gentrification, há meio século, supõe reexaminar os quadros contextuais que já não são os mesmos desde os anos 1960. Deve entender-se aqui por quadros contextuais tanto as especificidades dos territórios como as evoluções históricas (políticas econômicas, sociais...) e as do pensamento científico. Apresentar o caso do centro histórico de Lisboa não tem muito sentido sem este esforço para mostrar o que há de comum ou de diferente em relação aos outros casos estudados, não somente pelas suas características próprias, a história específica de Portugal ou da sua capital; mas também em relação à evolução de um pensamento científico português que se inscreve a meio caminho entre essas mesmas características e os referenciais exteriores passados ou presentes.

Uma vez essas precisões efetuadas, tentaremos demonstrar que em Lisboa o regime de desigualdades explica parcialmente as dinâmicas urbanas. Entendemos por dinâmicas urbanas, o conjunto de mudanças socioespaciais que afetam o espaço urbano desde a mobilidade dos grupos sociais no tempo e no espaço, até a evolução das paisagens, passando pelas transformações das infraestruturas urbanas. Essas dinâmicas são levadas pelos atores públicos que interagem sobre o território urbano em diferentes escalas. As desigualdades são, em primeiro lugar, socioeconômicas, espaciais, mas elas incidem também no acesso à cidade, ao habitat ou ao trabalho. Relembraremos que essas desigualdades são uma das características do centro histórico, por outro lado inscritas no tempo. E demonstraremos também que os intervenientes públicos (municipalidade, associações de bairro, etc.) integram essas desigualdades, ora intencionalmente ora inconscientemente, para levar a cabo projetos urbanos. Por fim, tentaremos colocar a questão do papel e do lugar da mobilização do conceito de gentrification nessas dinâmicas urbanas, para os intervenientes públicos locais.

Para compreender o terreno, as fontes não faltam. Trata-se em primeiro lugar das enquetes efetuadas pelas instituições nacionais (INE - Instituto Nacional de Estatísticas, IHRU - Instituto da Habitação e da Rehabilitação Urbana). Nós podemos agora seguir em três recenseamentos (1991, 2001 e 2011) os efeitos políticos da reabilitação do centro histórico pela municipalidade de Lisboa. É preciso contar igualmente com o trabalho dos serviços municipalizados que elaboram numerosos relatórios preliminares à elaboração dessas políticas. 0 município de Lisboa conservou também certos reflexos de planificação do antigo regime, ${ }^{1}$ com estruturas ${ }^{2}$ técnicas e administrativas inseridas no tecido local e devendo coletar informações e propor orientações aos serviços municipais e aos eleitos. Empenhada na modernização lançou-se também num projeto de "dados abertos"3 (Open Data LX) que permite a cada cidadão, mas também aos investigadores, aceder à maior parte das informações utilizadas pelos serviços municipais. Evidentemente a pesquisa de terreno no quadro da preparação de um doutoramento também é utilizada no nosso artigo; assim como os dados postos ao nosso dispor pelos parceiros locais da municipalidade (associações, ONG, comerciantes): relatórios, declarações públicas, entrevistas... Enfim, nós 
contamos também com os artigos na imprensa que fazem eco às dinâmicas do centro histórico de Lisboa.

\section{Reexaminar os contextos para compreender um terreno novo}

Perante a transformação das cidades inglesas e americanas logo após os anos 1960, os investigadores anglo-saxões começaram por tentar identificar os processos que observavam; em seguida, tentaram construir ferramentas que permitissem medir os efeitos desses processos nas sociedades e territórios. A socióloga Ruth Glass observa, no centro londrino, uma substituição pelas populações mais favorecidas, dos grupos sociais mais desfavorecidos (Glass, 1964). 0 que ela chama gentrification corresponde então a mecanismos essencialmente ligados aos jogos do mercado imobiliário, que têm a ver com o habitat construído após a $2^{\text {a }}$ Guerra Mundial, sem nenhuma unidade arquitetônica (Appert, 2008). 0 geógrafo Neil Smith vai mais longe fazendo do conceito de gentrification uma teoria que generaliza e sistematiza os efeitos socioespaciais (Smith, 1979). Para o investigador escocês que fez de Nova York o seu terreno de análise, os agentes públicos tecem estratégias para esvaziar os centros antigos das populações operárias e marginais em proveito de uma burguesia revanchista em busca da reconquista dos espaços que tinha deixado. Ele atribui essas lógicas às transformações do capitalismo. Com efeito os anos 1970 foram marcados por uma aceleração da internacionalização das trocas e 0 fim dos acordos de Bretton Woods. Esses dois acontecimentos podem ter servido para explicar que as grandes empresas e instituições públicas procuraram concentrar seus setores terciários em bolsas situadas no coração das grandes metrópoles (Sassen, 1991), enquanto as funções de produção conheciam as primeiras séries de deslocalização. É nesse duplo movimento que, para os investigadores, teria nascido a gentrification: uma parte das classes médias teria tentado aproximar-se das ofertas de emprego de serviços situadas nas proximidades dos centros urbanos antigos, enquanto as classes operárias foram levadas a migrar para o periurbano. 0 mercado imobiliário não é mais do que a tradução do fenômeno e da gentrification, a ilustração de um processo de produção de desigualdades socioespaciais segundo um modelo centro/periferia.

A proposta de Smith, porque estabelece uma ligação importante entre a análise científica e um discurso ideológico, ${ }^{4}$ impõe-se ao mesmo tempo como uma referência a mobilizar nos trabalhos sobre o espaço urbano, e como um tema de debate por si só na investigação mundial. No início, o autor distingue as cidades anglo-saxônicas e as cidades latinas do continente europeu. Essas não conheceriam segundo ele o fenômeno da gentrification. Essa posição explica as investigações levadas a cabo na Europa, por investigadores nomeadamente francófonos. ${ }^{5}$ Trata-se, para eles, de demonstrar que os centros mais antigos das cidades europeias conhecem também um processo de gentrification, o que conduz finalmente à generalização do conceito. Uma nova vaga de trabalhos a partir dos anos 2000 procura atenuar ou até formular reservas sobre essas aproximações (Bidou-Zachariasen, 2003) verificando no terreno de outras cidades as hipóteses 
desse último. Mas outros autores decidiram "desconstruir o conceito de gentrification" (Bourdin, 2008), duvidando de seu interesse na compreensão da territorialização.

Esses debates ecoam naturalmente em Portugal, mas com um desfasamento temporal. Certos autores retomam nas suas análises a ideia de entrada em concorrência das cidades no contexto da mundialização, e tentam medir os efeitos dessa concorrência sobre 0 mercado imobiliário (rent gap). É o caso de Luís Mendes que analisa o que está em jogo no marketing urbano sobre as dinâmicas espaciais e a imagem da cidade (2008). É necessário igualmente citar Eduardo Brito Henriques e Paulo Peixoto que contribuem para a popularização do conceito de gentrification nos meios da investigação em Portugal, nomeadamente a partir do estudo dos efeitos das mobilidades sobre o preço do imobiliário (Brito Henriques, 1994 ; Peixoto, 2000) e da qualificação do centro histórico por intermédio do patrimônio em benefício das classes médias (Peixoto, 2005). Duas ideias ressurgem amiúde nesses trabaIhos: a primeira insiste sobre a concorrência entre os agentes públicos e privados no seio do mercado imobiliário do centro histórico de Lisboa. São muitas vezes os arquitetos que põem essas questões por intermédio do que eles chamam os "riscos de gentrification" (Pavel, 2011). Na mesma lógica, mas numa perspectiva diferente, certos autores se preocuparam com a uniformização dos centros históricos pelo efeito das normas internacionais (Aguiar, 1999). Todos integram, aqui, as análises de Smith ou parecem caucioná-las.

0 que marca hoje são as grandes mudanças que aconteceram no contexto da análise e do próprio terreno: os próprios quadros ideológicos da guerra fria dissolveram-se, convidando o investigador a olhar diferentemente o objeto do estudo; as políticas públicas privilegiam hoje a densificação do espaço urbano por questões de economia orçamental e de domínio do território; por fim as recomendações internacionais, sustentadas por novas lógicas de governação evoluíram. Por exemplo o texto atualizado em 2003 da Nova Carta de Atenas (referência fulcral do Conselho Europeu dos Urbanistas) propõe um conjunto de recomendações para a cidade do século XXI que encontram um eco importante nas políticas públicas de reabilitações: coerências sociais e econômicas, coabitação pluricultural e socioeconômica entre as gerações, a identidade urbana, espírito do local, ou cidade participativa. Para a Unesco, "a preservação e a revitalização dos bairros históricos não pode ser feita sem os seus habitantes" (programa Historic Districts for all, em 2007).

Muito longe de serem declarações de princípios, essas recomendações foram largamente tomadas em conta pelos agentes locais, seja para obter financiamentos públicos seja para beneficiar dos selos de excelência e prêmios internacionais (Galhardo, 2013a). Assim pode ler-se no Plano Estratégico Local (PEL) de 2005:

[...] Lisboa, cidade das culturas, significa uma cidade que valoriza a coesão social, 0 cosmopolitismo, a criatividade, a tolerância e a abertura para o exterior, com o objetivo de promover uma cidade atrativa e contemporânea e que se quer cosmopolita e multicultural. Em Lisboa, vivem e trabaIham pessoas de inúmeras nacionalidades e de diferentes comunidades étnicas com seus respectivos valores culturais, que contribuem para o reforço do seu estatuto 
de metrópole multicultural e local de grande diversidade étnica e de convergência de culturas, nacionalidades e línguas.

No fim dos anos 2000, a integração do conjunto dessas intenções nas políticas públicas levou à atribuição de várias distinções a Lisboa, entre as quais uma da seção habitat da ONU pela sua prática de governança, a entrada do Fado no patrimônio mundial da Unesco, ou ainda premiada pela boa integração dos princípios da nova Carta de Atenas ou concurso Eurocities.

Essa evolução das normas internacionais orientou os pesquisadores portugueses para a questão do patrimônio ou da memória (Menezes, 2005; Pavel, 2011) e da cultura (Carranca, 2004; Costa, 2007) mais que a do conflito por apropriação e/ou a conservação do território. Nisso, parece-nos que a pesquisa portuguesa distinguiu-se por uma parte do quadro teórico avançado por Smith. Preferimos evocar aqui os processos de adaptação dos grupos sociais e a plasticidade dos territórios (Serrano e Neto, 2012), ao invés das lógicas de conflitos desenvolvidas e aprofundadas na pesquisa francesa (Melé, Larrue e Rosemberg, 2003). No entanto, nos últimos anos as reflexões francófonas, lusófonas e mais geralmente latino-americanas convergem para posicionamentos e interpretações de processos de territorialização em centro histórico bastante próximos. A maioria dos pesquisadores tenta tomar uma via intermédia entre uma análise que seria fundada sobre inter-relações bem sintonizadas (em contextos urbanos específicos) e a procura de novos paradigmas capazes de interpretar os fenômenos urbanos. Essa abordagem interessa mais nos fenômenos de proximidades e nas transações sociais (Melé, 2013). Os trabalhos sobre Lisboa de Malheiros, Carvalho e Mendes (2012) obedecem à mesma lógica. Esses últimos lembram que as transformações do centro histórico da capital portuguesa resultam da combinação de dois fenômenos: a fixação de imigrantes não europeus e a permanência de um enobrecimento ${ }^{6}$ urbano marginal.

Segundo eles, essa combinação tem como consequência uma diversificação cultural e étnica. A gentrification seria, então, uma simples característica de um fragmento do território. Menezes (2011) avança mesmo com a ideia de que a Mouraria (um dos bairros do centro histórico) seria um dos espelhos do espaço urbano contemporâneo, uma mancha onde coexistem diferentes Mourarias. Esses trabalhos fazem eco a preocupações muito práticas de eleitos que se interrogam sobre os processos de autossegregação socioespacial que acompanha a territorialização em Lisboa (Gaspar, 2003). Os trabalhos de Gaspar, apesar de uma certa inquietação diante do que ela identifica como um processo de exclusão do centro histórico das categorias desfavorecidas, mostram no entanto uma dispersão dos enclaves elitistas no território lisboeta. Ela nota igualmente que a escolha das novas elites difere das antigas.

\section{Persistência de desigualdades no centro antigo de lisboa}

0 centro histórico de Lisboa compõe-se de quatro bairros, chamados: Bairro Alto, Baixa-Chiado, Alfama e Mouraria (Figura 1). Nenhum desses bairros constitui uma unidade administrativa, mas suas existências devem-se ao modo como as memórias populares 
Figura 1 - Limites do bairro histórico e do seu centro antigo

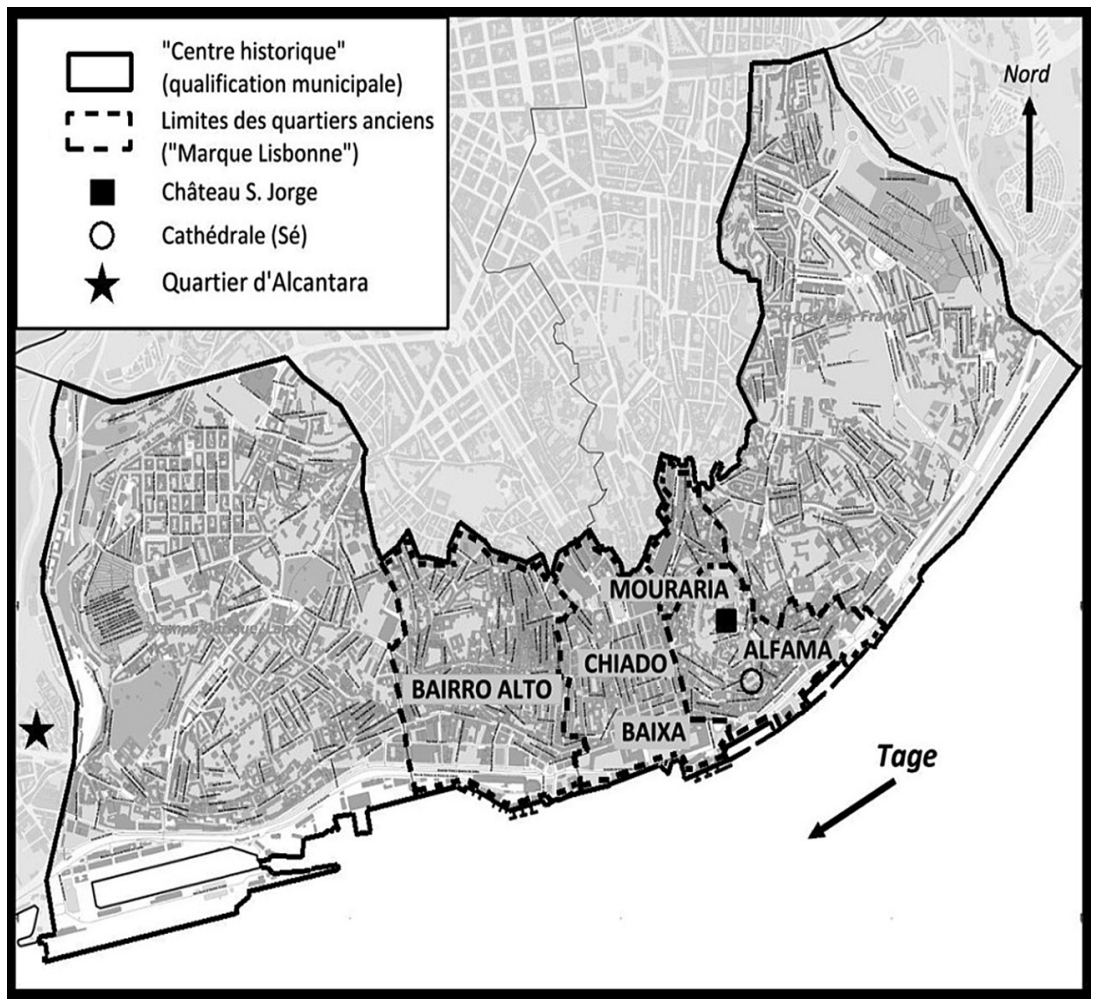

Fonte: CML (2012); Galhardo (2012).

facetaram - a partir das marcas mais ou menos visíveis nos espaços em causa - identidades coletivas específicas. ${ }^{7}$ A decisão municipal de fundir as doze freguesias ${ }^{8}$ mais antigas de Lisboa numa entidade política e administrativa única fez acordar as identidades locais e as resistências dos quatro bairros antigos. Em primeiro lugar o bairro de Alfama onde a primeira associação de gentrificadores aparece (1987) para defender a memória do fado e dos pescadores; em seguida o da Baixa-Chiado que tenta valorizar seu passado marítimo e comercial antes do grande incêndio em 1988 ter vindo distribuir as novas cartas da ação pública. 0 bairro alto, rapidamente designado como 0 local de predileção da vida noturna e cultura lisboeta, vive conflitos repetidos entre os comerciantes e a municipalidade, por causa da vida noturna, do estacionamento selvagem e das incivilidades. Por fim, o bairro da Mouraria durante muito tempo mal amado por causa da sua imagem de delinquência, pobreza e prostituição, revela desde os anos 2000 um interesse por parte das classes médias que se instalam e defendem seu passado árabe e uma certa multiculturalidade. 
Os eleitos observam e o apoiam, mas prudentemente. 0 programa diretor da requalificação do centro antigo de Lisboa tem essa vontade de diferenciar e ter em conta as desigualdades socioespaciais até nos títulos utilizados: "as cidades dentro da cidade" ou ainda "uma cidade de bairros". Esse programa foi integrado quando do documento de enquadramento votado pela Assembleia Municipal em 2010: "Lisboa 2012, Visão estratégica". Resta o fio vermelho da planificação urbana lisboeta e resulta do trabalho dos pesquisadores do Instituto Superior Técnico de Lisboa. Esses últimos imaginaram um projeto de revitalização da cidade contemporânea que permita conciliar as estratégias de compactagem e de policentralização consideradas como a base da organização e do desenvolvimento urbano (Fernandes, 2009). No plano teórico, a desigualdade espacial admite-se como um elemento positivo do território. Os pesquisadores que trabalharam nesse pressuposto mostram que pode justificar-se com 0 passado territorial.

Historicamente, Lisboa desenvolve-se em torno do Castelo de S. Jorge, no período da presença dos mouros. Após a tomada da cidade pelos cristãos em 1170, um primeiro recinto protegido é construído. Alfama se densifica na parte sul, ao longo do Tejo, no interior das muralhas. A parte alta, em torno da catedral, é ocupada pela nobreza e as famílias ricas, enquanto a parte baixa é deixada aos pescadores e marinheiros. Quando na Idade Média as populações endinheiradas migram para a rua da Madalena e a Baixa, os pescadores e marinheiros estendem-se mais para cima na colina. Na parte norte, no exterior das muralhas, o bairro da Mouraria nasce de uma concessão atribuída aos mouros que não foram todos expulsos. São muitas vezes os proprietários de grandes explorações agrícolas que alimentavam o castelo. A pesquisa histórica refere também artesãos de arte, mas esses habitantes vão ser pouco a pouco substituídos pelas famílias cristãs, consoante as perseguições. $\mathrm{Na}$ parte baixa (Baixa-Chiado) encontravam-se as atividades comerciais relativas às descobertas e atividade portuária.

Os reis deixam o castelo e aí se instalam desde o século XVI arrastando com eles a elite portuguesa. 0 terremoto de 1755 destruiu 0 bairro e obrigou o poder público a reconstruir, de modo mais racional (Figura 2), o espaço à volta da Praça do Comércio. É lá que se instalam mais tarde os grandes armazéns de luxo, os teatros e as salas de espetáculo. Enfim o Bairro Alto, cuja forma em xadrez é anterior à Baixa-Chiado, resulta de uma política de parcelamento levada a cabo pelos poderes públicos sobre terrenos agrícolas, entre os séculos XVI e XVII. A monarquia aí instalou a partir de 1498 a população cujas atividades estavam ligadas ao rio e ao mar. Mesmo assim o bairro, a partir de 1551, viveu um enobrecimento e emburguesamento parciais, com a instalação das famílias seguindo os jesuítas que se fixaram em torno da igreja de S. Roque, nos pequenos palácios ainda visíveis.

A história do centro antigo marca o território não só pelo seu urbanismo, mas também pela sua arquitetura: na Baixa-Chiado existe um plano em xadrez com alojamentos bastante vastos e relativamente bem equipados, mas esse não é o caso do Bairro Alto (igualmente em xadrez), onde, ao lado dos pequenos palácios que deram lugar estes últimos anos a pequenas operações fachadistas, encontram-se pequenos 
Figura 2 - Plano em xadrez e antigo enobrecimento da Baixa-Chiado

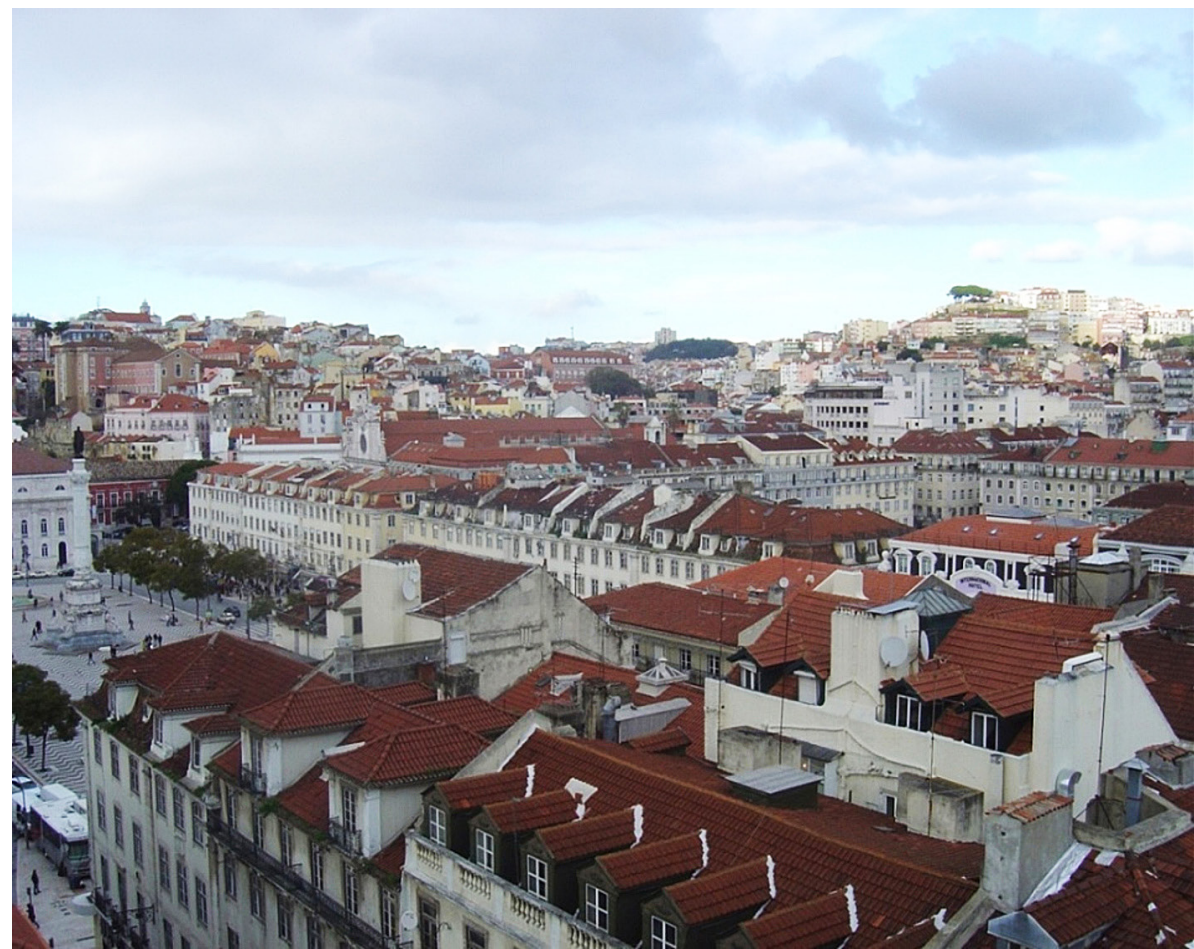

Fonte: Galhardo (2010).

alojamentos de vários andares insalubres. No oposto Alfama e Mouraria (Figura 3) vivem situações diferentes: casas bastante opulentas no pé do castelo e pequenas casas insalubres mais abaixo da colina. Nos dois casos, as ruas são estreitas e sinuosas. Não se pode no entanto falar de Medina, mas simplesmente de um urbanismo pouco dominado e pouco controlado. 0 que sobressai aqui é a diversidade de situações e características, tanto entre cada bairro como no interior dos próprios bairros. Essa diversidade tem a marca das desigualdades socioespaciais. Os trabalhos mostram que existe, continuamente, um dinamismo urbano em torno das alternâncias povoamento/abandono e proletarização/enobrecimento. Os próprios processos parecem, aliás, nunca ter fim: a um enobrecimento, mais ou menos parcial, sucedem-se episódios de proletarização provisória. Pavel (ibid.) relata que depois do terremoto as elites trocam o centro antigo pela periferia de Lisboa e alugam os alojamentos às famílias pobres. 0 município irá adquirir os pequenos palácios em ruínas durante o século XIX para levar a cabo novas intervenções sobre o território. 
Figura 3 - Diversidade arquitetônica da Mouraria

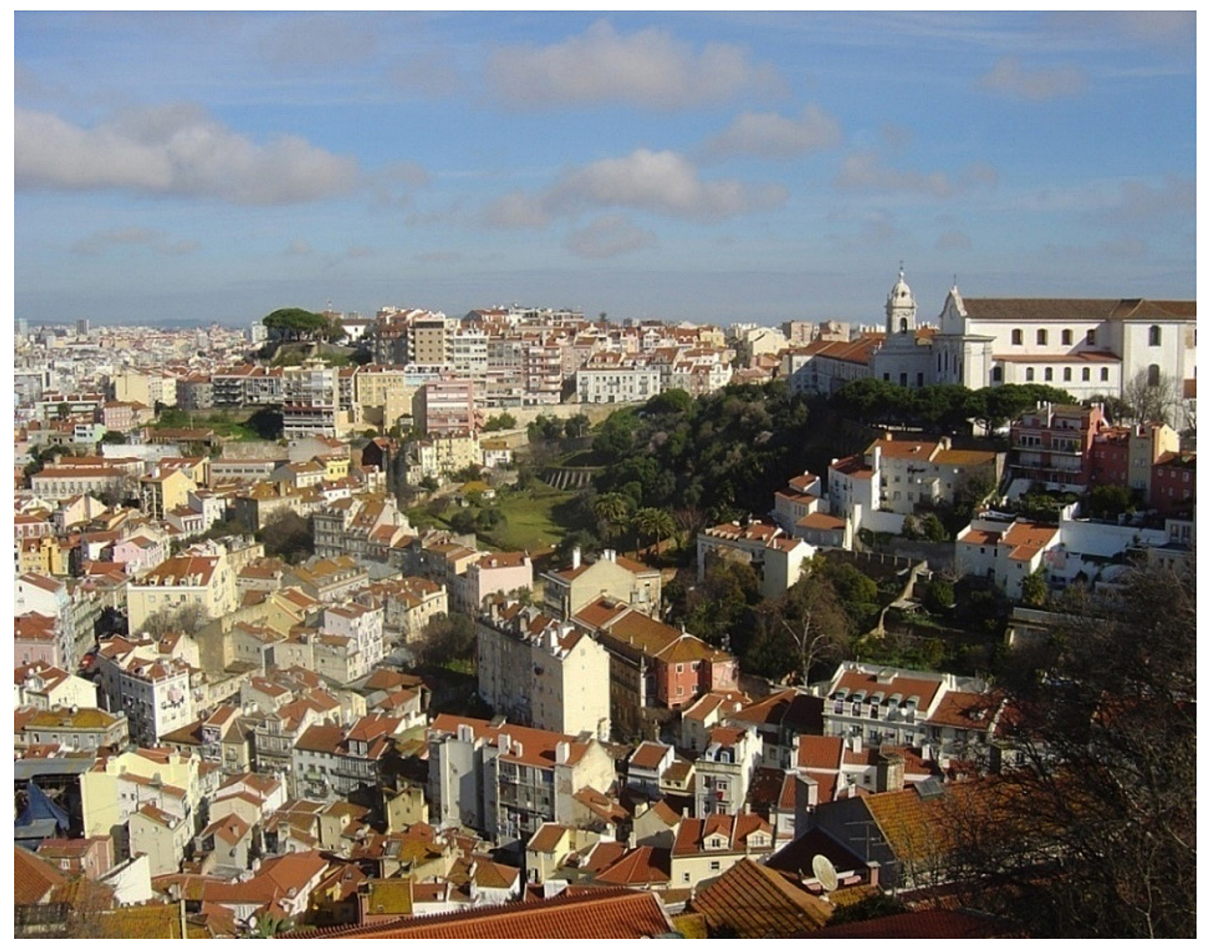

Fonte: Galhardo (2010).

Neste primeiro período, o espaço que corresponde ao centro antigo atual de Lisboa vive a divisão tradicional das sociedades do mar: bairros de marinheiros polivalentes e pobres, bairros dos oficiais, e os dos mercadores-negociantes, aos quais juntamos os palácios da elite aristocrática. Ainda que segregada, a proximidade socioespacial e a dependência intergrupos explicam-se pelos imperativos de uma atividade portuária em concorrência com outros portos da fachada atlântica (Sevilha, Bordéus, Nantes e Londres). A elite desta sociedade do mar lisboeta é a principal beneficiária dos produtos importados e organiza a cidade para facilitar as trocas comerciais. A instalação da monarquia para a Baixa-Chiado corresponde sem dúvida a sua vontade de dominar uma parte dos fluxos comerciais e da cota dos produtos importados que são desembarcados na Praça do Comércio. Se o terremoto de 1755 marca a retirada das monarquias para as periferias, nessa altura já Lisboa não rivalizava com os portos franceses, holandeses ou ingleses. Longe de dar origem a uma pauperização geral do centro da capital, os trabalhos de reconstrução da Baixa-Chiado mantêm-se "uma grelha de ruas que estabelece uma rede viária e que ao mesmo tempo estabelece uma hierarquia 
social e comercial" (Camarinhas, 2006). 0 autor $^{9}$ acrescenta que "só as insuficiências financeiras do governo e do Município evitaram a destruição dos bairros populares de Alfama e Mouraria, para os quais se propunham projetos arquitetônicos de ilhas operárias modernas". No primeiro caso, as desigualdades são integradas nas políticas públicas para racionalizar o espaço e dominar as dinâmicas. No segundo caso, a ausência de meios age como adiamento de ação pública cuja consequência é a continuação de um nível elevado de desigualdades.

Os anos 1930 e as décadas a seguir à $2^{a}$ Guerra Mundial não parecem desmentir essa continuidade de um espaço heterogêneo, apresentando microterritórios muito desiguais, diversidade sociológica e econômica, urbanismo, habitat... Durante esse período Portugal não vive processos econômicos próprios dos Estados industriais depois da $2^{\text {a }}$ Guerra Mundial: permanece um Estado totalitário com mais de $50 \%$ de população rural, fechado sobre ele próprio e o seu império, e prisioneiro da ideologia autárquica. Entre 1945 e 1947, o governo de Salazar lança uma série de programas de habitação cujo objetivo é responder à crise do alojamento garantindo ao mesmo tempo a paz social e ao mesmo tempo lutar contra as desigualdades. Vários segmentos da população mais fragilizada são o alvo mantendo uma fragmentação do espaço urbano lisboeta e do mercado imobiliário (Silva, 1987): as casas econômicas cujo objetivo é de encontrar uma solução ao problema de habitação das classes operárias ${ }^{10}$ (1933); as casas desmontáveis destinadas aos antigos habitantes das favelas (1938); as casas para famílias pobres que não tinham recursos suficientes para aceder às casas econômicas (1945); ou as casas de renda econômica para as classes médias (1946-1947); o programa de casas de renda limitada (1947) cujo congelamento dos aluguéis vai ter uma incidência sobre a degradação do patrimônio construído. A partir de 1948, o governo liberaliza os montantes dos aluguéis em todas as cidades portuguesas com exceção de Lisboa e Porto.

Silva (1994) conclui em três pontos: por um lado, o setor privado continua a ser o principal agente da construção no mercado imobiliário, apesar do regime autoritário; por outro, o jogo dos agentes produz uma situação extremamente variável tanto no povoamento como nas características da construção; conclusão, nem o Estado nem o setor privado conseguem no fim de contas resolver a crise do alojamento. Por outras palavras, ao sair da ditadura, a oferta (qualidade da construção, tamanho, equipamentos...) continua a ser extremamente diversificada, mantendo em Lisboa desigualdades socioespaciais. Padeiro e Costa (2013) $)^{11}$ relembram que um dos efeitos do crescimento demográfico na aglomeração é o "aparecimento de 'bairros clandestinos' na periferia nos terrenos com vocação paisagística ou agrícola feito sob o olhar complacente das autoridades públicas mal preparadas". Esses mesmos bairros ou loteamentos clandestinos (e também favelas) vão mais tarde ser legalizados, normalizados (re)qualificados... com duas consequências: a permanência das desigualdades sobre esses territórios e a metropolização de Lisboa. Entretanto, os squats e alojamentos ilegais ${ }^{12}$ são hoje ainda uma realidade em Lisboa, e não só nas periferias. Ou seja, a história da cidade, da sua evolução, das suas transformações e dos seus ordenamentos deve-se, em primeiro lugar, à existência das desigualdades que os atores 
querem tratar com maior ou menor amplitude, ambição ou sucesso.

0 período que segue à Revolução dos Cravos (25 de abril de 1974) marca a junção das políticas públicas territoriais às normas internacionais em evolução sobretudo a partir da entrada de Portugal na Comunidade Econômica Europeia (1986). No entanto, essas normas internacionais já levam em conta o fim dos "trinta gloriosos" e a entrada em concorrência dos homens e dos territórios no quadro de processos econômicos mundializados: a importância das cidades e dos litorais (e acessoriamente das zonas ribeirinhas), a necessidade de associar os cidadãos às decisões (para evitar os efeitos onerosos dos conflitos), a questão ambiental (no espaço público ou privado), o papel da cultura e do patrimônio na valorização territorial e a imagem de marca da cidade (com a intervenção permanente das memórias locais e da encenação da cidade), os interesses de reterritorialização de uma população que se tornou mais móvel, etc. Todos esses assuntos são integrados, sem hesitações, nas políticas públicas municipais a partir dos anos 1980 com efeitos sobre o centro histórico de Lisboa, mas com nuances.

As estatísticas do INE revelam bastante bem a existência de desigualdades no centro histórico apesar das políticas públicas que, ao requalificar o espaço, deveriam trazer investimentos e categorias sociais mais favorecidas. Se nos basearmos nos dados coletados em 2001, Lisboa tem $65,1 \%{ }^{13}$ de habitantes sem qualificação ou simplesmente com nível de ensino primário (Ensino Básico). Todos os bairros históricos do centro antigo estão acima deste valor: $74,5 \%$, no Bairro Alto; $80,2 \%$, em
Alfama; e 81,5\% na Mouraria. Do lado oposto, os habitantes que dispõem de um diploma universitário superior ou igual a uma licenciatura representam 14,6\% em Lisboa; 8,7\% no Bairro Alto; 6,1\% em Alfama; e somente 4,7\% na Mouraria. É notável que a diferença em relação à média em Lisboa não permite dizer que os bairros são apreciados pelos gentrificadores, até 2001. Notaremos, no entanto, as diferenças entre os três bairros. Enquanto a fase de reabilitação está em fase de acabamento em Alfama e que o Bairro Alto está a meio das primeiras grandes obras, é esse que parece fixar a população mais qualificada que em Alfama.

Essas observações são confirmadas pelo indicador do Recurso Mínimo de Inserção. ${ }^{14}$ Assim entre 2005 e 2007, o número de beneficiários passou de 80 a 212 na Mouraria (+165\%), de 56 a 219 em Alfama (+291,1\%) e 115 a $276(+140 \%)$ no Bairro Alto. Ou uma população precária vem para esses bairros ou a população local fica mais precarizada (pode também ser melhor identificada pelos serviços sociais). Aqui ainda, a diferença entre os três bairros históricos são notáveis, obrigando-nos a agudizar a análise. Assim sendo, se observamos uma população ativa no bairro da Mouraria, que é composto por duas entidades administrativas (Socorro a norte e São Cristóvão perto de Alfama e do Castelo), nós obtemos os seguintes números: as categorias superiores representam 10,48\% no Socorro e $16,24 \%$ em São Cristóvão, nas categorias médias, respectivamente $50,44 \%$ e $47,55 \%$, enquanto nas categorias mais fracas o número permanece ainda muito elevado: $39,8 \%$ no Socorro e $36,21 \%$ em São Cristóvão. 
Figura 4 - Extrato do mapa da tipologia de estabelecimentos nas freguesias do Concelho de Lisboa, 2010.

O bairro histórico está delimitado em azul
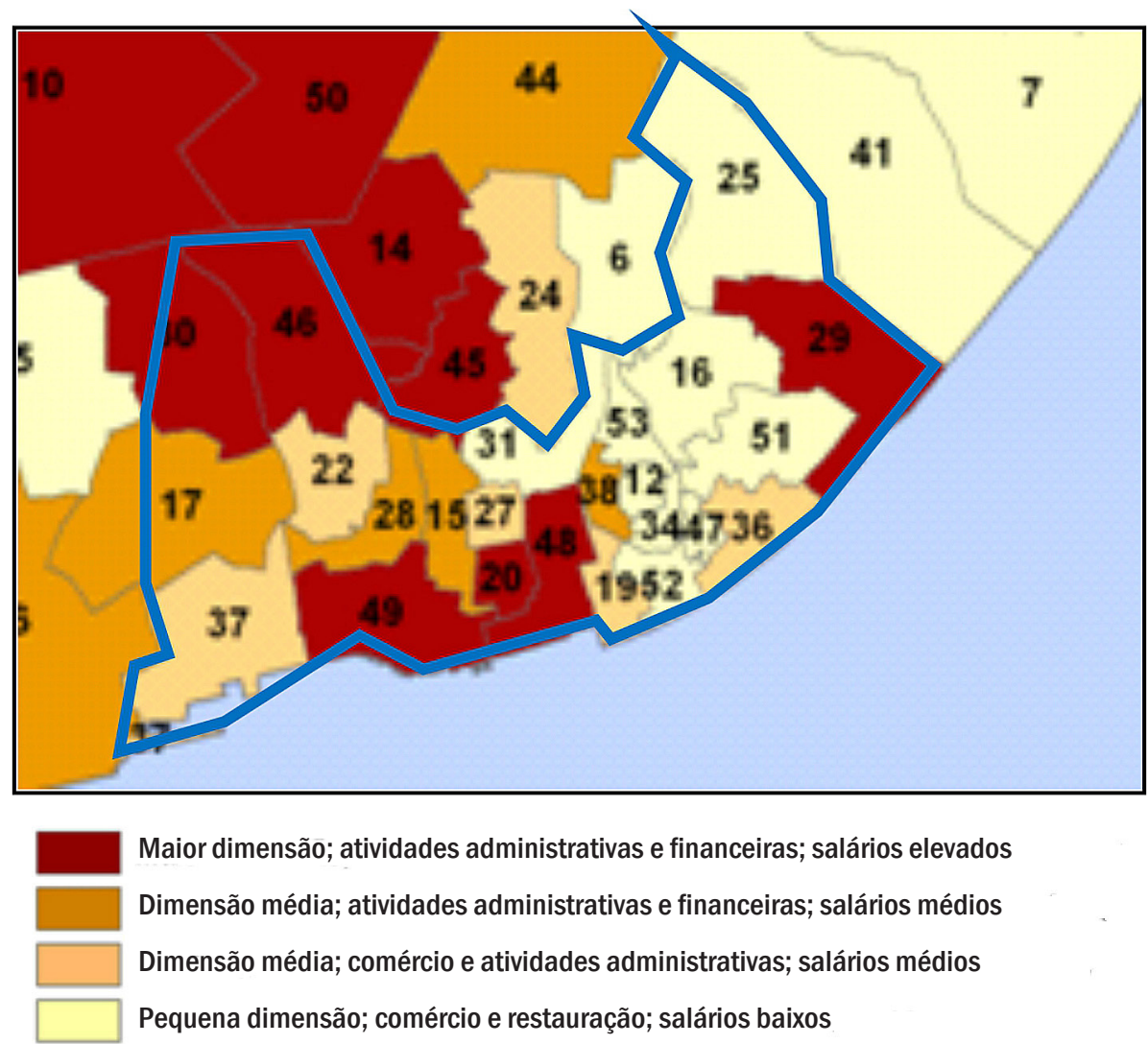

Fonte: Observatório das Desigualdades - CIES-ISCTE e Galhardo (2014).

E igualmente nesse sentido que Margarida Carvalho e Renato Miguel do Carmo concluem para o Observatório das Desigualdades, ${ }^{15}$ em 2010: "mas a aparente posição privilegiada de Lisboa em relação ao resto do país, esconde situações de grande desigualdade e diferencial salarial". Os autores desse relatório notam que o ratio entre os salários mais elevados e os mais baixos na capital é superior em dois pontos ao do país em geral. E concluem então: "isto significa que apesar dos ganhos médios mensais em Lisboa serem superiores aos nacionais existe uma maior disparidade desses ganhos". 0 que nós observamos no centro de Lisboa é a persistência de um mosaico de situações apesar das políticas públicas desenvolvidas pela municipalidade desde os anos 1980 (Figura 4 - estabelecida a partir da carta do Observatório das Desigualdades). ${ }^{16}$ 
Estamos longe de um processo de gentrification que se estenderia ao centro histórico no seu conjunto, empurrando as populações mais modestas ou precarizadas. A prostituição, o tráfico de droga e as várias atividades ilícitas não desapareceram. Estão nas manchetes dos jornais e são levados em conta nas politicas públicas locais. Sem querer generalizar os comportamentos marginais ou estigmatizar certos bairros históricos, essas características espaciais são testemunho de uma coabitação lógica entre categorias socioeconômicas diferentes: as primeiras fornecem um serviço lá onde se encontram os potenciais clientes graças a um poder de compra elevado.

\section{0 regime de desigualdades, motor de dinâmicas urbanas}

Se as desigualdades persistem no centro histórico de Lisboa, apesar das políticas públicas de reabilitação, ${ }^{17}$ então é conveniente rever as hipóteses de interpretação das dinâmicas urbanas. Desde os anos 1930, os agentes públicos utilizaram diferentes aproximações para tentar reabilitar o centro histórico: uma fase de monopólio quase exclusivo das instituições públicas (1933-1948); uma fase durante a qual as instituições concederam algumas prerrogativas limitadas ao setor privado (1948-1974); uma fase de busca de parceiros institucionais (19751990); uma fase de retirada institucional e de confiança no setor privado (1990-2006); uma fase durante a qual o município se contenta de um papel limitado pontual e relativo através de uma ação pragmática de parcerias e conceitos abertos (desde 2006).
Durante esse último período, os agentes públicos locais procuram sair das obrigações teóricas e normativas que se impõem pelos documentos da planificação urbana. Um duplo contexto determina essa orientação: as normas internacionais cada vez mais apressadas, pois caucionam os financiamentos e 0 reconhecimento internacional; e um território marcado por desigualdades persistentes e a diversidade da procura dos utentes dos bairros do centro histórico.

A municipalidade de Lisboa beneficiou desde o início dos anos 1990 de um arsenal jurídico e financeiro extremamente rico e diversificado, suscetível de responder, finalmente, às situações muito desiguais do seu território. 0 Estado continua a acompanhar as políticas públicas locais por intermédio de uma série de programas financeiros ${ }^{18}$ que dizem respeito ao aluguel, ajuda ao financiamento da reabilitação, a fiscalidade ou o mercado imobiliário. Assim, o Estado reforma o regime dos aluguéis urbanos $^{19}$ fixando novos coeficientes que visam em princípio 0 aumento global dos aluguéis antigos preservando ao mesmo tempo as populações mais modestas. ${ }^{20}$ Essa lei modificada e completada por intermédio de decretos de aplicação, tem por objetivo dar aos proprietários os meios financeiros para reabilitar os seus bens. Esses beneficiam assim de ajudas variáveis, como o SOLARH (três decretos-lei entre 1999 e 2001) que permite à IHRU oferecer empréstimos sem juros para realizar obras de conservação num habitat pertencente a privados ou aos agentes públicos (associações, instituições, municipalidades). Para responder às dificuldades de realojamento, o Estado implementa dois programas especiais: Prohabita (seis decretos-lei e três decisões ministeriais entre 1989 e 
2007) é um programa de medidas de urgência das famílias cuja habitação está destruída, ameaçando ou destinada à demolição. A ajuda vai desde o alojamento provisório num hotel, até a reconstrução da habitação, passando pela procura de alojamentos disponíveis para os habitantes. A ajuda supõe acordos de colaboração entre os municípios ou as associações de municípios e o IHRU. A esse programa junta-se outro específico das áreas urbanas de Porto e Lisboa (os mais povoados): o programa especial de realojamento (PER - oito decretos-lei e quatro decisões ministeriais entre 1989 e 2007). Tem por objetivo o realojamento das pessoas que vivem nas favelas ou squatters urbanos. Para encorajar os particulares a entrar nesses dispositivos, o Estado português toma uma série de iniciativas de caráter fiscal para os particulares, previstas no orçamento de Estado de 2008: baixa do IVA e das taxas imobiliárias e/ou sobre os aluguéis, sobre as obras em curso em certos tipos de edifícios. A lei prevê que essas isenções duram de 5 a 8 anos. Por outro lado, um conjunto de textos regulamentares enquadram o mercado imobiliário, os preços de compra do $\mathrm{m}^{2}$, os montantes destinados às alienações de bens... Esses textos reagem também às regras e aos custos de construção, às ajudas e aos subsídios à aquisição assim como às transmissões de bens (ou a sua impossibilidade) assim como os direitos aferentes. Por fim, esses textos evocam as ajudas e as garantias para certas categorias de cidadãos (pessoas idosas, jovens...).

A diversidade do arsenal jurídico legal e fiscal ilustra a vontade quase cirúrgica de integrar as desigualdades nas políticas públicas nomeadamente para controlar e limitar seus efeitos não esperados. Tudo se passa como se os atores públicos tivessem admitido a necessidade de manter todos os grupos sociais no teatro urbano. Essa vontade de uma inclusão das desigualdades manifesta-se, por exemplo, pelo conteúdo do relatório final inscrito no Quadro de Referência Estratégica Nacional (QREN) dedicado à inclusão social dos indivíduos residentes em territórios urbanos problemáticos (relatório final, 2013) que associa a municipalidade, os profissionais (conselhos, auditorias) e as associações de bairro (gentrificadores). Para esses atores instituídos trata-se de manter (ou de restabelecer) um direito à cidade para todos através da promoção de soluções financeiras e sociais suportadas pelos parceiros locais. No seu trabalho sobre Alfama (2011), Benis reporta um encontro com um dos arquitetos (F. Lopes) que tinha participado nestas políticas públicas nos anos 1980:

0 nosso trabalho foi uma experiência muito dirigida ao social e aos pobres. Essa intervenção mínima permitiu manter nesses bairros uma grande parte da população. Ou seja, se hoje há uma certa vida popular local que dá, nesta época as festas populares, este ambiente de bairro, é porque conseguimos manter uma parte da população que tem seus hábitos e que, por outro lado, está adaptada às condições de vida desses bairros (porque efetivamente essas ruas estreitas e essas pequenas casas não são aceites nem favorecem certos tipos de população, nem são aceites por uma população mais emburguesada). Essas pessoas estão habituadas e gostam tanto desse ambiente que não querem partir. 
Benis mostra em seguida que esta política de permanência de populações pobres ao lado de populações mais desafogadas, no contexto novo (liberalismo municipal e global dos anos 1990), favorece o desencadear do processo do que ela chama "gentrification incontrolada" do bairro. Se o autor constata a partida de um número importante das populações alfamistas, outros igualmente modestos mantêm-se no bairro ao lado dos novos burgueses-boêmios. São essas desigualdades que Benis revela nas fotografias que mobiliza e nas conversas que realiza. No caso de Alfama como no caso de outros bairros do centro antigo de Lisboa, o objetivo das políticas públicas não é a luta contra as desigualdades mas sim sua inclusão para não agravar a consequências socioespaciais. Por esse fato as desigualdades podem manter-se no centro antigo, ou mais concretamente em fragmentos do território. No caso de Alcântara, antigo bairro industrial situado à margem do centro antigo, Giroud (2007) analisa os efeitos das políticas públicas e conclui sobre as forma de resistência habitando o espaço público, a rua..., por parte das populações que deixaram seus alojamentos.

0 município mediu em 2008 o grau de adesão dos agentes públicos locais aos dispositivos legais da reabilitação em centro antigo. Assim, se considerarmos o conjunto de dispositivos de ajudas financeiras (Recria, RECRIPH, Rehabita e SOLARH) apresentadas anteriormente constatamos no período 1988-2005, ${ }^{21}$ que os bairros históricos centrais não reagem todos da mesma maneira: ${ }^{22} 106$ processos iniciados para a Mouraria (5,7\% da Área Histórica Central), 224 quanto a Alfama (11,6\% do $A H C)$ e 341 para o Bairro Alto $(17,7 \%$ da $\mathrm{AHC})$. Se medirmos os níveis de acabamentos nas unidades de habitação familiar em relação ao número total de unidades, observamos as mesmas diferenças: 18,9\% na Mouraria, $25,9 \%$ em Alfama e $30,7 \%$ no Bairro Alto. As mesmas fontes mostram que esse fenômeno evolui ao longo do tempo. Para o Bairro Alto, os pedidos de financiamento não cessam de aumentar entre 1988 e 1999, baixando logo em seguida. 0 número de pedidos é menos elevado na Mouraria, e a evolução varia muito de ano para ano. Vários elementos explicam essas variações e diferenças. Vamos reter aqui a propriedade e o estado do construído existente. Se tivermos em conta os alojamentos vazios $^{23}$ (total ou parcialmente), constatamos que são $12,7 \%$ na Mouraria, 29,25\% em Alfama e $9,67 \%$ no Bairro Alto. A propriedade dos alojamentos vazios também pode explicar as resistências dos agentes locais na reabilitação pelas capacidades financeiras dos proprietários. 0 peso da Igreja, que pouco pretende especular, é mais importante na Mouraria que nos dois outros bairros centrais antigos. 0 mesmo se aplica ao município que tem praticamente $1 / 5$ dos alojamentos vazios da Mouraria, 4\% em Alfama e 15\% no Bairro Alto. São os privados que mais possuem alojamentos vazios, cerca de $75 \%$ na Mouraria e outro tanto no Bairro Alto, e mais de $91 \%$ em Alfama. 0 resultado dessas políticas são limitados para não dizer fracassos, aquando, dos recenciamentos de 1991 e 2001, os alojamentos vazios passam na Mouraria de $8 \%$ a $34,1 \%$ do total, em Alfama de $11 \%$ a $25,7 \%$ e de $12,8 \%$ a 21 , $8 \%$ no Bairro Alto. Evidenciam a partida regular dos habitantes e o abandono dos moradores, mas também as especulações imobiliárias. No período de 1981 a 1991, a Mouraria perde $29 \%$ de sua população, Alfama $30,5 \%$ e 0 
Bairro Alto quase $40 \%$. Na década seguinte, a queda continua: $36,5 \%$ na Mouraria, $34,8 \%$ em Alfama e 16,41\% no Bairro Alto.

Aqui é claramente o Bairro Alto que se implica na oferta de reabilitação. É verdade que esse bairro dispõe de vantagens comerciais e atividades culturais que se cruzam com a pobreza e interessam os investidores privados. No lado oposto, sem dúvida pelo peso das instituições, a Mouraria parece menos implicada na via da reabilitação. 0 que mostram as estatísticas é a desigualdade de acesso ao centro antigo seja pelas populações com forte capital econômico e social ou inversamente pelos que menos têm. 0 caso da Mouraria é interessante na medida em que a ação voluntarista da municipalidade não desencadeou imediatamente um processo de gentrification. 0 principal resultado foi a natureza da propriedade de bens imobiliários e as estratégias de especulação dos proprietários (privados e a Igreja católica). 0 atraso acumulado em relação aos outros bairros históricos e a estigmatização socioespacial de um território tornado marginal no coração do centro antigo acabou por dar início a uma política de reabilitação financiada pela UE, o Estado e a municipalidade. Muito minoritários na parte baixa do bairro, os gentrificadores criam uma associação sociocultural (renovar a Mouraria) cuja presidência é bicéfala: uma recém-chegada (classe média setor da saúde, investe na aça social) e um "filho do bairro" 24 (sem qualificação, no desemprego, setor do espetáculo). Um e outro sem descanso vão tentar associar todas as populações do bairro nas negociações com a municipalidade, os discursos, as narrativas...; mas também a organizar atividades que associem os mais modestos, os estrangeiros, os estudantes...; com mais ou menos sucesso.
Finalmente, se a disponibilidade de bens imobiliários tem um papel importante nas dinâmicas do mercado, a variedade da oferta parece ser primordial para um agente desse setor. Um estudo dos serviços do plano e urbanismo (CML, 2005a) orienta os eleitos para o desenvolvimento dessa diversidade para responder a uma procura cujas caraterísticas testemunham a parte importante das desigualdades entre pretendentes a um alojamento (aluguel ou em acesso a propriedade) à Lisboa. As políticas municipais ulteriores terão essa preocupação, mas ao invés das políticas aplicadas antes da Revolução dos Cravos, a ação pública é mais pensada na globalidade socioespacial. No documento municipal (CML, 2005b) que anuncia os grandes eixos da planificação futura, o centro antigo é apresentado como uma "marca de Lisboa" suscetível de atrair novos habitantes e investidores internacionais. 0 Programa de Ação Municipal ( As Cidades dentro da Cidade) lançado em 2009 indica que "é necessário encontrar uma maneira de abordar no seu todo o centro histórico de Lisboa, sob pena de ver os territórios que não fariam parte dos programas de regeneração, acentuar as estigmatização e a getização". A ação pública apoia-se sobre as desigualdades constatadas, mas parece limitar-se a não as acentuar.

No decorrer do nosso trabalho de campo, desde 2010, observamos poucos documentos públicos (municipais ou associativos) que utilizem o termo de gentrificação (reservado aos pesquisadores). Do mesmo modo, a questão da exclusão ou da pobreza aparece pouco explicitamente no espaço público. No melhor dos casos, está associada à inclusão. Na realidade as desigualdades dissimulam-se por detrás de novos conceitos de ação pública como a 
multiculturalidade ou a apologia do "cruzamento das culturas". ${ }^{25}$ Que parecem eclipsar os termos de gentrificação fragmentação ou as ideias exclusivas. A vontade de evitar discussões conflituosas ou um conceito demasiado negativo de um território é a primeira razão, mas não é provavelmente a única. Trata-se igualmente de ganhar tempo nos projetos de reabilitação e de controlar os orçamentos em tempos de crise. Uma tal pressão convida os atores a serem pragmáticos e a um reequilíbrio das forças nas negociações.

\section{As desigualdades: um elemento como outro qualquer nas políticas locais}

Vimos que as desigualdades são uma constante do centro histórico de Lisboa, em todas as épocas. Observamos igualmente que os enclaves, compostos de populações favorecidas ou nem por isso, não estão estáticas no tempo nem no espaço: os processos de gentrificação (enobrecimento) ou de proletarização (desclassificação) tiveram situações. Seja como for nenhum desses processos tem fim, aqui como noutros lados (Authier, 2001; Bacqué, 2006). Os fatores explicativos são numerosos, conhecidos e declinam-se em todas as escalas. Podem resumir-se numa regra recorrente de concorrência entre os seres humanos e dos territórios segundo objetivo de performance. No caso descrito por Smith, o papel do Estado (ou das municipalidades) no financiamento da requalificação dos bairros centrais era tão importante como o do mercado imobiliário ou dos efeitos das mudanças do capitalismo sobre os territórios urbanos, para explicar a gentrificação. Contudo em Lisboa, o Estado e a municipalidade desencadearam o processo de gentrificação ao procurar pelo contrário reter as populações modestas. As políticas públicas que pretendiam requalificar o centro antigo nos anos 1990 tiveram efeitos variáveis: alguns bairros do centro antigo conheceram fases de gentrificação (Alfama), outros pelo contrário nenhuma (Mouraria). É necessário procurar as explicações nas características do território, mais do que nas políticas públicas que se esforçaram em ter em conta as desigualdades. Posteriormente as instituições locais e nacionais tiveram de acomodar-se às novas normas internacionais que pediam a luta contra a pobreza e favorecer explicitamente a permanência das populações modestas no centro antigo. Longe de constituir um obstáculo às desigualdades socioespaciais foram ponto de partida para novas alianças entre gentrificadores e autóctones para novas forma de qualificações espaciais.

Confrontada com as restrições das ajudas nacionais e europeias desde 2006, o município de Lisboa visa os sítios exatos do centro antigo onde desenvolver sua política de reabilitação ancorada nos conceitos internacionais: a Frente Tejo (seguindo os critérios de waterfronts), a Praça do Comércio (ao mesmo tempo cruzamento e entrada de cidade), a praça Martim Moniz (que se tornou Festival Market Place com o seu mercado fusão) ou ainda o eixo que vai do Largo do Intendente ao Largo de São Cristóvão, através da Mouraria (designada como eixo da multiculturalidade e do patrimônio). Essa seletividade dá origem a ângulos mortos que deixam à disposição das iniciativas privadas. Essas jubilam perante a diversidade da oferta, mas a crise econômica não lhes permite tirar largos benefícios do mercado imobiliário 
bem aberto. Meios desiguais continuam a facetar um território desigual como pelo passado.

Os agentes públicos procuram, por outro lado, igualmente preservar no centro antigo as populações marginais ou em dificuldades. Eles são conduzidos pelas normas internacionais que condicionam as ajudas às políticas de inclusão social, mas também porque o direito à cidade implica - num segundo tempo - a questão dos deveres inerentes. 0 projeto de reabilitação da Mouraria, financiado pela Comunidade Europeia, copilotado pela municipalidade e as associações presentes no bairro, não exclui a reabilitação de bens e a normalização dos locais comerciais sobretudo se essas populações animam a vida do bairro e incarnam um certo folclore propício às dinâmicas gentrificadoras turísticas (Figura 5). 0 projeto inclui também ajudas às populações imigrantes (alfabetização, ajuda perante as administrações...), dispositivos sanitários e sociais (para prostituição e tóxico-dependência), mas também um banco do tempo (para mutualizar os serviços prestados entre os habitantes segundo as competências).

Figure 5 - Esplanada reabilitada de uma tasca na Praça da Severa

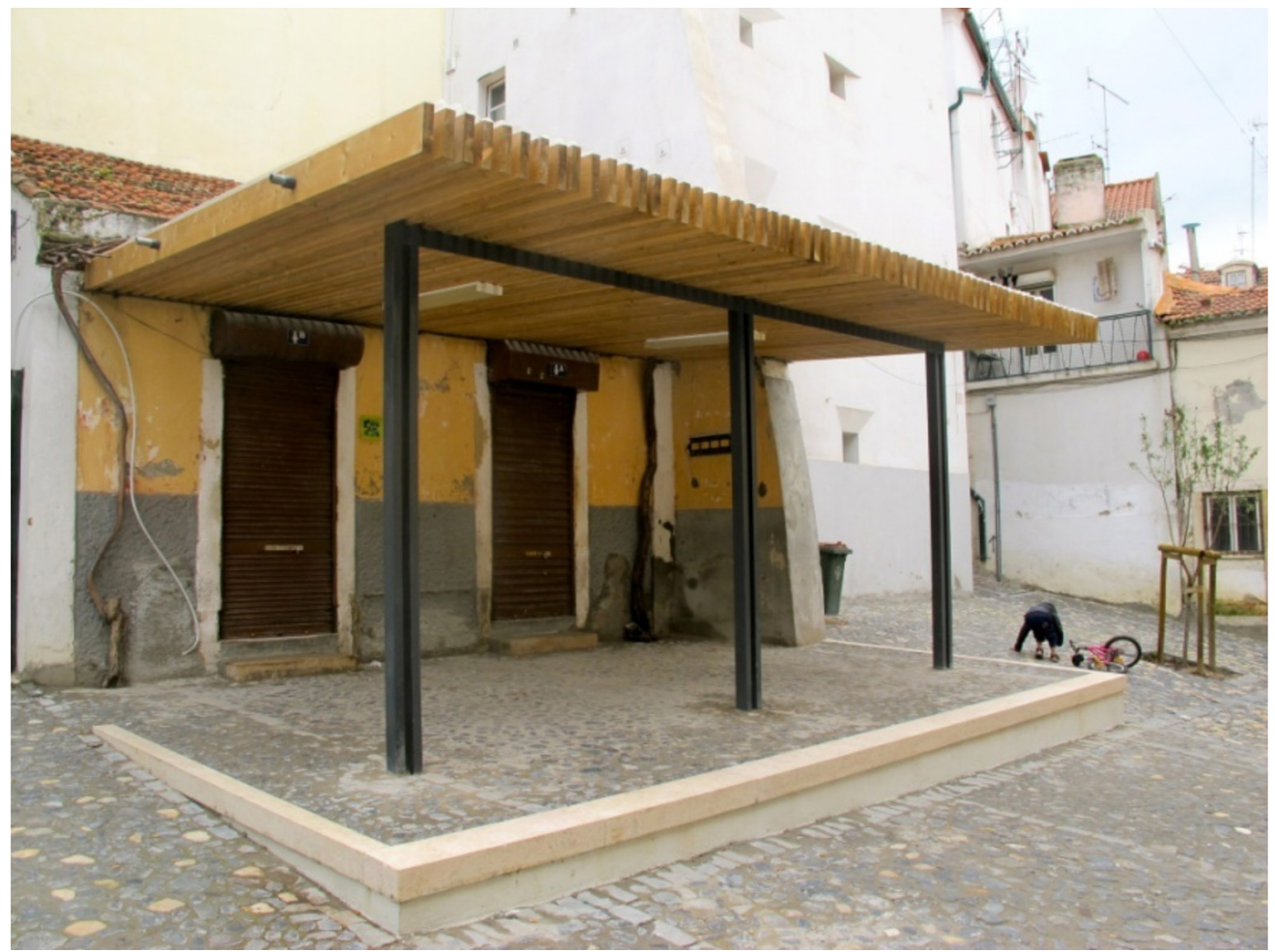

Fonte: Galhardo (2012). 
Tabela 1 - Quadro da população residente com emprego em 2001 e 2011 nas duas freguesias da Mouraria, segundo os grupos profissionais

\begin{tabular}{|c|c|c|c|c|c|c|c|c|c|c|}
\hline & \multicolumn{5}{|c|}{ São Cristóvão e Lourenço } & \multicolumn{5}{|c|}{ Socorro } \\
\hline & 2001 & 2011 & $\begin{array}{c}\text { Var. } \\
2011 / 2001 \\
(\%)\end{array}$ & $\begin{array}{c}\% \text { pop. } \\
\text { total } \\
(2001)\end{array}$ & $\begin{array}{c}\% \text { pop. } \\
\text { total } \\
(2011)\end{array}$ & 2001 & 2011 & $\begin{array}{c}\text { Var. } \\
2011 / 2001 \\
(\%)\end{array}$ & $\begin{array}{c}\% \text { pop. } \\
\text { total } \\
(2001)\end{array}$ & $\begin{array}{c}\% \text { pop. } \\
\text { total } \\
(2011)\end{array}$ \\
\hline Grupo 1 & 43 & 32 & $-25,58$ & 6,13 & 6,01 & 50 & 61 & 22 & 4,33 & 4,84 \\
\hline Grupo 2 & 71 & 133 & 87,32 & 10,11 & 25 & 71 & 128 & 80,3 & 6,15 & 10,17 \\
\hline Grupo 3 & 71 & 57 & $-19,72$ & 10,11 & 10,71 & 94 & 78 & -17 & 8,15 & 6,2 \\
\hline Grupo 4 & 76 & 42 & $-44,74$ & 10,83 & 7,89 & 162 & 110 & $-32,1$ & 14,04 & 8,74 \\
\hline Grupo 5 & 184 & 154 & $-16,3$ & 26,21 & 28,94 & 326 & 538 & 65 & 28,25 & 42,76 \\
\hline Grupo 6 & 1 & 3 & 200 & 0,14 & 0,56 & 6 & 2 & $-66,7$ & 0,52 & 0,15 \\
\hline Grupo 7 & 96 & 33 & $-65,63$ & 13,68 & 6,2 & 108 & 98 & $-9,3$ & 9,36 & 7,8 \\
\hline Grupo 8 & 21 & 9 & $-57,14$ & 2,99 & 1,69 & 71 & 23 & $-67,6$ & 6,15 & 1,82 \\
\hline Grupo 9 & 138 & 68 & $-50,72$ & 19,66 & 12,58 & 264 & 218 & $-17,4$ & 22,88 & 17,32 \\
\hline Grupo 10 & 1 & 1 & 0 & 0,14 & 0,18 & 2 & 2 & 0 & 0,17 & 0,15 \\
\hline Total & 702 & 532 & $-24,2$ & 100 & 100 & 1154 & 1258 & 9 & 100 & 100 \\
\hline
\end{tabular}

Grupo1: Quadros superiores da administração pública, dirigentes e quadros superiores / Grupo 2: Profissões intelectuais e científicas / Grupo 3: Técnicos e profissionais de nível intermédio / Grupo 4: Pessoal administrativo e assimilados / Grupo 5: Pessoal de serviços e vendedores / Grupo 6: Agricultores e trabalhadores qualificados (agricultura e pesca) / Grupo 7: Operários, artesãos e assimilados / Grupo 8: Operários de instalação e de máquinas e trabalhadores fabris / Grupo 9: Trabalhadores não qualificados / Grupo 10: Pessoal das forças armadas. Fonte: INE.

Os resultados dessas ações públicas são ainda difíceis de interpretar. As últimas estatísticas do INE (Tabela 1) mostra que nas duas antigas freguesias da Mouraria as profissões intelectuais e científicas aumentaram desde 2001 de 87,32\% em São Cristóvão, e 80,3\% no Socorro. Esse grupo representa $1 / 4$ dos habitantes de São Cristóvão e 10,17\% do Socorro. Pelo contrário, o recenciamento de 2011 mostra bem uma baixa das categorias mais modestas (Grupos 7, 8 e 9). Poderemos falar de gentrification? Há sem dúvida um duplo movimento de partidas das populações modestas e de chegada de populações mais favorecidas. Será necessário conhecer o destino das populações que partem: deixam Lisboa ou vão para outro bairro incluindo o centro antigo? $\mathrm{Na}$ periferia ou na capital? Enquanto se espera por uma análise mais fina noutras escalas, constatamos: permanência das populações operárias no centro antigo: 20,47\% em São Cristóvão e $26,94 \%$ no Socorro. Se tivermos em conta os três primeiros grupos mais favorecidos: $41,72 \%$ en São Cristóvão e somente $21,21 \%$ no Socorro. 0 processo de gentrification não afeta a Mouraria no seu conjunto: só uma parte do bairro interessa às categorias mais favorecidas da população. 0 que nos interessa nessas estatísticas é uma outra população intermédia (pessoal de serviços e vendedores) 
que representam 28,94\% em São Cristóvão e $42,72 \%$ no Socorro: uma relação quase inversa em relação aos grupos favorecidos. Numa sociedade cada vez mais terceirizada, a questão que se põe é saber se as desigualdades não estão a instalar-se entre esses dois grupos. Uma aproximação pelos recursos permitiria melhor entender essa problemática socioespacial.

\section{Conclusão: o lugar da gentrificação no novo contexto urbano?}

As políticas públicas municipais não reforçam nem reduzem as desigualdades socioeconômicas e socioespaciais. É provável que aí se alimentem para iniciar e justificar a ação pública local. Foi o caso explicitamente quando o contexto promovia o papel do Estado todo poderoso (totalitarismo ou Estado-providência): tentava-se lutar contra as desigualdades por intermédio de programas de ajudas cuja natureza e ferramentas variavam segundo o grau de desigualdade. Em centro antigo, essas intervenções puderam favorecer uma certa gentrificação, mais ou menos extensa revelando assim o empowerment dos atores locais e suas resistências às dinâmicas espaciais. 0 que observamos hoje é mais uma contabilização das desigualdades como um fator natural do território e que não podem ser absorvidas: quer dizer um dado a ter em conta no quadro SWOT+ $+\mathrm{T}^{26}$ ou uma maneira de limitar os conflitos, os atrasos e os custos adicionais. Neste campo, a promoção da democracia participativa em Lisboa, nomeadamente através do orçamento participativo anual, ilustra bem essa contabilização das desigualdades no debate cidadão (Galhardo, 2013b).

As análises de Neil Smith e de Ruth Glass que conduziram à elaboração do conceito de gentrificação são ineficazes ou inadaptadas 50 anos depois? É difícil falar de revanchismo quando se constata a coabitação e a integração das desigualdades nas políticas municipais e as ações das organizações de gentrificadores. Houve com certeza uma certa substituição das populações operárias por populações com forte capital material e intelectual; no entanto, esse movimento foi limitado e podemos pôr a hipótese que possa ser provisório: certos indicadores do INE foram analisados como um início de desgentrificação de Alfama. Com efeito, as mobilidades profissionais e a evolução das famílias (chegada de crianças) tornam difícil a permanência desses burgueses-boêmios em certos apartamentos exíguos e por vezes mal equipados, mal servidos de transportes e com serviços públicos (escolas e creches...) raras. Mas de resto se os operários estão menos presentes em centro antigo, outras categorias proletarizadas aí aparecem: empregados de limpeza, agentes de manutenção, domésticos, serviços aos particulares, vendedores... A gentrificação permanece um fenômeno cujos fatores são complexos e os efeitos variáveis no espaço e no tempo. 


\section{Jacques Galhardo}

Universitè François Rabelais-Tours, CItés, TERritoires, Environnement, Sociétés (CITERES), Construction Politique et Sociale des Territoires. Tours, França.

alhogard37@yahoo.fr

\section{Notas}

(1) A ditadura salazarista.

(2) Para o plano diretor municipal foi instalada uma Unidade de Projeto (UP) em cada bairro histórico.

(3) Com outras 11 cidades no mundo: Baltimore, Barcelona, Berlim, Chicago, Helsinque, Londres, Manchester, Nova York, Paris, São Francisco e Washington.

(4) Marcada aqui pelo desencantamento dos intelectuais anglo-saxões em relação ao modelo americano liberal, criticado pelas suas intervenções, num contexto de guerra fria: Chile, Guerra do Vietnã.

(5) Jean Lojkine, Francis Godard, Edmond Préteceille, pela França, mas também Horácio Capel, Manuel Castells, pela Espanha.

(6) As posições científicas encontram-se no vocabulário utilizado. Certos autores preferem o termo de "enobrecimento" (ou até "nobilização") ao termo de "gentrificação". Um e outro designam o mesmo fenômeno, mas "o enobrecimento" adianta a ideia de uma melhoria qualitativa mais geral, não só sociológica mas também espacial. O termo revela, por outro lado, uma preocupação que procura escapar às considerações demasiado políticas.

(7) É o que os lisboetas chamam espírito "bairrista'.

(8) Nome das unidades políticas e administrativas da municipalidade de Lisboa.

(9) Que cita os anais da municipalidade de Lisboa de 28 de maio 1858, p. 197.

(10) Decreto-lei n. 23052, de 23 de setembro de 1933.

(11) Citando a obra de Silva, R. E. L. D. (2007). Metodologia para identificação das margens urbanas metropolitanas por abordagem multi-estratégica. Uma aplicação à área metropolitana de Lisboa. Mestrado em Gestão do Território, Universidade Nova de Lisboa.

(12) O Público: "Lisboa: mais de 170 casas da autarquia ocupadas de forma ilegal”. Agência Luso, 7 jun 2010.

(13) Um número já elevado para uma capital europeia, mas que esconde desigualdades entre os bairros lisboetas e entre Lisboa e suas periferias. Os trabalhos de Teresa Salgueiro Barata abordaram largamente estes temas essenciais para a compreensão das dinâmicas da capital portuguesa. Nós pensamos na sua obra, Lisboa. Periferias e centralidades (2006) nas edições Harmattan. Poder-se-ia também referir à revista Sud-Ouest-Européen, n. 24, de 2007: Lisboa e as suas periferias, nas edições Presses Universitaires du Mirail.

(14) Rendimento mínimo de inserção social. Fontes municipais. 
(15) http://observatorio-das-desigualdades.cies.iscte.pt/index.jsp?page=projects\&id=119

(16) Aqui só são medidos os estabelecimentos profissionais e os rendimentos salariais.

(17) Quer dizer apesar dos métodos e as ferramentas utilizadas, assim como as teorias presidindo a construção do território.

(18) Um decreto-lei, de 31 de julho de 1996, estabelece um Regime Especial de Co-participação e de Financiamento no quadro da recuperação de Imóveis Urbanos em Regime de Propriedade Horizontal (RECRIPH): destina-se a autorizar o financiamento das obras de conservação nas partes comuns de edifícios construídos em propriedade horizontal (terreno e vias em propriedade comum, mas habitat em propriedade individual, a aproximar dos loteamentos) pela associação de diferentes parceiros. E também uma ajuda ao financiamento das reabilitações (Recria: Regime Especial de Comparticipação na Recuperação de Imóveis Alugados (Regime Especial de Co-participação na Recuperação de Imóveis para locação) foi decidida em 1999. Essa ajuda tem por objetivo permitir o financiamento da conservação e as melhorias nas unidades de habitação familiar e imóveis degradados, pelo Estado e pelos municípios. No entanto ela só diz respeito ao habitat cujos aluguéis são objeto de correções e de ajustes (três decretos-lei e uma decisão ministerial entre 1999 e 2006). A essa ajuda seguem-se dois decretos-lei e uma decisão ministerial entre 1996 e 2006, que estabelecem um Regime de Ajuda à Recuperação de Habitat nas Zonas Urbanas Antigas (Rehabita: Regime de Apoio à Recuperação Habitacional em Áreas Urbanas Antigas). É uma extensão do programa Recria, aplicado às zonas urbanas reconhecidas pelo seu interesse histórico ou patrimonial. Isso supõe que os municípios que vão se beneficiar desse programa tenham contratado acordos com os IRHU e/ou com outras instituições de crédito autorizadas.

(19) Novo Regime de Arrendamento Urbano.

(20) Os coeficientes são calculados anualmente a partir de um recurso mínimo utilizado como referencial.

(21) Entre a entrada de Portugal na CEE e o fim da segunda parte do programa comunitário URBAIN II no qual "Lisboa participa desde 1994 no quadro dos bairros em crise. Mas também no período de elaboração dos principais dispositivos legais financeiro e fiscais pelo Estado incidindo sobre os territórios municipais.

(22) Fonte: INH - Instituto Nacional de da Habitação, e IHRU, 2005.

(23) Fonte: CML - Câmara Municipal de Lisboa.

(24) Retomando a expressão utilizada por Marluci Menezes.

(25) O Público: A Lisboa d'Antonio Costa, 9 mai 2009.

(26) Strengths, Weaknesses, Opportunities, and Threats+Tendences). Ferramenta dos consultores em economia e finanças, utilizado pela municipalidade de Lisboa para implementar suas políticas. 


\section{Referências}

AGUIAR, J. (1999). A cidade do futuro já existe hoje. Algumas notas sobre reabilitação urbana. ATIC Magazine. Lisbonne, n. 24.

APPERT, M. (2008). Londres: metropole globale. Géocarrefour, v. 83, n. 2, pp. 113-117.

AUTHIER, J. Y. (org.). (2001). Du domicile à la ville. Vivre en quartier ancien. Paris, Anthropos.

BACQUE, M.-H., (2006). En attendant la gentrification: discours et politiques à la Goutte d'Or (19822000). Sociétés contemporaines, v. 3, n. 63, pp. 63-83.

BENIS, K. (2011). Impactos da "gentrificação" sobre a apropriação do espaço público. Dissertação de Mestrado. Lisboa, Universidade Técnica de Lisboa.

BIDOU-ZACHARIASEN, C. (org.). (2003). Retours en ville - des processus de "gentrification" urbaine aux politiques de "revitalisation" des centres. Paris, Descartes et Cie. Coll. Les urbanités.

BOURDIN, A. (2008). Gentrification: un “concept” à déconstruire. Espaces et sociétés, v. 1-2, n. 132, pp. 23-37.

BRITO HENRIQUES, E. (1994). Vender a cidade ou as lógicas e as estratégias do marketing urbano. Finisterra, v. 58, n. 29, pp. 403-406.

CAMARINHAS, C. (2006). "De l'avenue-promenade au greenway: I'utopie de l'Urbain à Lisbonne". In: COLLOQUE CULTURES ET MEDIATION. Communications. Universidade de Tours.

CARRANCA, M. A. (2004). Uma cultura para a sociedade do conhecimento: contributos da cultura para a promoção das cidades como habitats de inovação. GeoNova, n. 10, pp. 77-99.

COSTA, P. (2007). A cultura em Portugal, competitividade e desenvolvimento territorial. Lisboa, ICS.

CML (2005a). Habitação e Mercado Imobiliário na Área Metropolitana de Lisboa. Lisboa, Câmara Municipal de Lisboa.

(2005b). Visão Estratégica - 2012. Documento de quadro da planificação municipal. Lisboa, Câmara Municipal de Lisboa.

(2012). Disponível em: http://www.cm-lisboa.pt/zonas/centro-historico.

FERNANDES, J. P. C. (2009). Cidades dentro das cidades. O projecto urbano na revitalização da cidade contemporânea. Dissertação de mestrado. Lisboa, Universidade Técnica de Lisboa.

GALHARDO, J. (2013a). Ville et mondialisation, le centre ancien de Lisbonne. Le Globe, T. 153, Universidade de Genebra.

(2013b). Plasticité et pragmatisme des dispositifs participatifs à Lisbonne. In : 3EMES JOURNEES DOCTORALES SUR LA PARTICIPATION ET LA DEMOCRATIE PARTICIPATIVE - GIS DEMOCRATIE ET PARTICIPATION. Actes. Disponível em: http://www.participation-et-democratie.fr/fr/node/1626

GASPAR, L. B. D. (2003). Auto-segregação socioespacial em lisboa. Estudos Regionais, n. 4, pp. 75-93.

GIROUD, M. (2007). Résister en habitant? Renouvellement urbain et continuités populaires en centre ancien (Berriat Saint-Bruno à Grenoble et Alcântara à Lisbonne). Tese de doutorado. Poitiers, Université de Poitiers.

GLASS, R. (org.). (1964). "Introduction”. In: CENTRE FOR URBAN STUDIES. Londres, aspects of change. Londres, Macgibbon e Kee, pp.12-41. 
MALHEIROS, J., CARVALHO, R. e MENDES, L. (2012). Etnicização residencial e nobilitação urbana marginal: processo de ajustamento ou prática emancipatória num bairro do centro histórico de Lisboa? Sociologia, Revista da Faculdade de Letras da Universidade do Porto. Número temático: Imigração, Diversidade e Convivência Cultural, pp. 97-128.

MENEZES, M. (2003). Mouraria: entre o mito da Severa e o Martim Moniz. Estudo antropológico sobre o campo de significações imaginárias de um bairro típico de Lisboa. Lisboa, LNEC.

(2005). Património Urbano: por onde passam a sua salvaguarda e reabilitação? Uma breve visita à Mouraria. Cidades - Comunidades e Territórios, n. 11, pp. 65-82.

(2011). "Todos” na Mouraria? Diversidades, desigualdades e diferenças entre os que vêm ver o Bairro, nele vivem e nele querem viver. In: XI CONGRESSO LUSO-AFRO-BRASILEIROS DE CIÊNCIAS SOCIAIS. Diversidades e (des)Igualdades. 7-10 ago. Salvador, Universidade Federal da Bahia.

MELE, P.; LARRUE, C. e ROSEMBERG, M. (2003). Conflits et territoires. Tours, Presses Universitaires François Rabelais, Villes et Territoires.

MELE, P. (dir.). (2013). Conflits de proximité et dynamiques urbaines. Rennes, Presses Universitaires de Rennes.

NETO, P. e SERRANO, M. (2012). “Identidade e a plasticidade territorial e os processos de regeneração urbana". In: VII CONGRESSO PORTUGUÊS DE SOCIOLOGIA: SOCIEDADES, CRISES E RECONFIGURAÇÕES. Anais. Porto, Universidade do Porto.

PADEIRO, M. e MARQUES DA COSTA, N. (2013). L'aire métropolitaine de Lisbonne à la croisée des chemins. Le Globe, T. 153, Universidade de Genebra.

PAVEL, F. (2011). Bairro Alto: renovação e reabilitação, identidade e risco de gentrification. In: VIII CONGRESSO IBERICO D'URBANISMO: a mudança do ciclo: um novo urbanismo. 27-29 out. Anais. Covilhã, Universidade da Beira Interior

PEIXOTO, P. (2000). Gestão estratégica das imagens das cidades: análise de mensagens promocionais e de estratégias de marketing urbano. Revista Crítica de Ciências Sociais, n. 56, pp. 99-120.

(2005). Porto Feliz: patrimônio em segurança. Horizontes Antropológicos, n. 23, pp. 145-161.

RELATÓRIO FINAL (2013). Contributo das intervenções do QREN para a inclusão social de indivíduos residentes em territórios urbanos problemáticos. Lisboa, Observatório do QREN (Secretaria Geral do Ministério das Finanças)

SASSEN, S. (1991). The global city, New York, London, Tokyo. Princeton, Princeton University Press.

SILVA, C. N. (1987). Planeamento Municipal e a Organização do Espaço em Lisboa: 1926-1974. Lisboa, CEG/INIC.

(1994). Mercado e políticas públicas em Portugal: a questão da habitação na primeira metade do século XX. Análise Social, v. 29, n. 127, pp. 655-675.

SMITH, N. (1979). Toward a theory of gentrification a back to the city movement by capital, not people. Journal of the American Planning Association, v. 45, n. 4, pp. 538-548.

Texto recebido em 14/out/2013

Texto aprovado em 3/fev/2014 